\title{
Efficacy and safety of subconjunctival bevacizumab for recurrent pterygium
}

\section{Eficácia e segurança da aplicação subconjuntival de bevacizumabe em pterígio recidivado}

Larissa Rossana Souza Stival ${ }^{1}$, Anelise Medeiros Lago ${ }^{1}$, Marisa Novaes Falleiro Chaves de Figueiredo ${ }^{1}$, Ricardo Henrique Goulart Bittar ${ }^{1}$, Márcia leite Machado ${ }^{1}$, João Jorge Nassaralla Junior ${ }^{1,2}$

\begin{abstract}
Purpose: To evaluate the clinical outcome(s) and complication(s) of subconjunctival bevacizumab treatment in patients with recurrent pterygium.

Methods: This prospective case series included patients who had undergone pterygium surgery and were diagnosed with recurrent pterygium. All patients received one subconjunctival injection of $0.5 \mathrm{~mL}$ of bevacizumab $(2.5 \mathrm{mg} / 0.1 \mathrm{~mL})$. The main outcome was the change in size and clinical appearance. The clinical appearance of the pterygium was graded according to Tan and colleagues. The horizontal size of the pterygium (from limbus to apex) was recorded from baseline to 2 months after injection. Treatment-related complications and adverse events were reported.

Results: We included 36 eyes of 36 patients $(18$ males) with a mean age of $58.75 \pm 10.98$ years. Totally, $30.6 \%$ patients developed recurrent pterygium in both eyes (only the worst eye was treated), with $47.2 \%$ developing it in the left eye and $22.2 \%$ in the right eye. More than half the patients (58.3\%) had a family history of pterygium. There was a significant difference in the size of pterygium at different intervals $(P<0.05)$. Approximately two-thirds $(66.7 \%)$ of patients presented with hyposphagma on the $2^{\text {nd }}$ day after subconjunctival application; this value decreased to $30.6 \%$ by day 7 and to $0 \%$ at 1 month. Most patients (69.4\%) exhibited amelioration of irritative symptoms within 2 days, $88.9 \%$ after 7 days, and $97.2 \%$ after 1 month
\end{abstract}

Conclusions: Subconjunctival bevacizumab injection is useful for the management of patients with recurrent pterygium, with no significant local or systemic adverse effects.

Keywords: Pterygium; Recurrence; Antibodies, monoclonal/therapeutic use; Angiogenesis inhibitors/administration \& dosage; Injections

\section{RESUMO}

Objetivo: Avaliar os resultados e complicações da injeção subconjuntival de bevacizumabe em pacientes com pterígio recidivado.

Métodos: Série de casos prospectiva envolvendo pacientes submetidos à exérese de pterígio que foram diagnosticados com pterígio recidivado. Todos pacientes receberam uma aplicação subconjuntival 0,5 $\mathrm{ml}$ de bevacizumabe $(2,5 \mathrm{mg} / 0,1 \mathrm{ml})$. O principal resultado foi a mudança no tamanho dos pterígios. A aparência clínica do pterígio fol graduada de acordo com os critérios de Tan et al. O tamanho horizontal do pterígio (do limbo ao ápice) foi observado até 60 dias semanas após a injeção. Os efeitos adversos e as complicações do tratamento foram descritos.

Resultados: Foram incluídos 36 olhos de 36 pacientes (18 masculinos) com média de idade de $58,75 \pm 10,98$ anos. 30,6\% dos pacientes tinham pterígio recidivado em ambos os olhos (apenas o pior olho foi tratado), $47,2 \%$ no olho esquerdo e $22,2 \%$ no olho direito Mais da metade dos pacientes (58.3\%) possuíam história familiar de pterígio. Houve uma diferença estatisticamente significante no tamanho do pterígio em diferentes intervalos $(P<0,05) .66,7 \%$ dos pacientes apresentaram hemorragia subconjuntival no segundo dia após a aplicação, diminuindo para 30,6\% no sétimo dia e nenhum paciente após um mês. A maioria dos pacientes $(69,4 \%)$ teve melhora dos sintomas irritativos após dois dias, 88,9\% após 7 dias e $97,2 \%$ após um mês.

Conclusão: $A$ injeção subconjuntival de bevacizumabe é uma alternativa válida na condução de pacientes com pterígio recidivado, não apresentando efeitos locais e sistêmicos significantes.

Descritores: Pterígio; Recidiva; Anticorpos monoclonais/uso terapêutico; Inibidores de angiogênese/administração \& dosagem; Injeções

\section{INTRODUCTION}

Pterygium is characterized by the encroachment of a fleshy fibrovascular tissue from the bulbar conjunctiva onto the cornea. Although historically described as a degenerative disorder, it is more closely associated with inflammation and progressive fibrovascular proliferation $^{(1-3)}$.

The pathogenesis of pterygium appears to be complex. Despite being historically described more as a degenerative process, inflammation and fibrovascular proliferation are currently proven to be important factors. Angiogenesis has also been demonstrated during pterygium formation and progression ${ }^{(4-5)}$.

The current treatments for pterygium focus on surgical excision and prevention of recurrence. The extent and severity of the fibrovas- cular growth of pterygium seem to comprise a reliable morphological index for predicting recurrence after surgery ${ }^{(6)}$.

Recurrence of pterygium is the most common undesirable outcome after surgical excision. Recurrent pterygia are more hazardous than primary ones because the underlying cornea may be thinner. Extensive scarring from previous procedures can adversely affect visual acuity, and further recurrence is common ${ }^{(7)}$.

Several studies have shown that the increased expression of basic fibroblast growth factor (bFGF), transforming growth factor (TGF- $\beta$ ), vascular endothelial growth factor (VEGF), and platelet-derived growth factor correlates with the formation and recurrence of pterygia ${ }^{(8-11)}$.

Bevacizumab (Avastin ${ }^{\oplus}$, Genentech, Inc., San Francisco, CA, USA) is a humanized monoclonal antibody to VEGF designed for intravenous (IV) administration and approved for the treatment of colorectal
Submitted for publication: June 13,2013 Accepted for publication: October 5, 2013 Study carried out at Instituto de Olhos de Goiânia.

Goiânia Eye Institute, Goiânia, Goiás, Brazil.

Department of Ophthalmology, Faculty of Health Sciences, Universidade de Brasília, UNb, Brasília (DF), Brazil.
Funding: No specific financial support was available for this study.

Disclosure of potential conflicts of interest: L.R.S. Stival, None; A.M. Lago, None; M.N.F.C. Figueiredo, None; R.H.G. Bittar, None; M.L. Machado, None; J.J. Nassaralla Jr, None.

Correspondence address: Larissa Rossana Souza Stival. Rua 2, 708 - Apto. 701 - Ed. Thitara Park Setor Oeste, Goiânia (GO) - 74110-130 - Brazil - E-mail: larissastival@hotmail.com

ClinicalTrials.gov ID- NCT01744756

Research Ethics Committee: Goiania Eye Institute, Goiania, Goiás, Brazil. 
cancer ${ }^{(11)}$. Various clinical trials have shown that intravitreal administration is well tolerated and associated with an improvement in visual acuity, decrease in central retinal thickness, and decrease in angiographic leakage $e^{(12,13)}$.

Pterygia are composed of proliferating fibrovascular tissue, and pterygium formation and progression require new blood vessel formation ${ }^{(14)}$. Prominent regression of limbal-conjunctival neovascularization and delayed recurrence have been reported with the use of topical bevacizumab in patients with impending recurrent pterygium $^{(15-16)}$.

Anti-VEGF therapy may potentially suppress neovascularization in pterygium, preventing or retarding the progression of recurren$\mathrm{ce}^{(17-19)}$. This study aimed to determine the clinical effectiveness and safety of subconjunctival injection of bevacizumab for recurrent pterygium.

\section{METHODS}

This was a prospective, single-dosing, interventional case series conducted at Instituto de Olhos de Goiânia (Goiânia Eye Institute), a hospital in Goiânia (Brazil), from March 2012 to December 2012 in patients with recurrent pterygium. Recurrent pterygium was defined as the growth of fibrovascular tissue over the limbus onto the clear cornea in the area of previous pterygium excision.

The pterygia were graded according to the system used by Tan et al. ${ }^{(6)}$ : grade I (atrophic), in which the episcleral vessels under the body of the pterygium are not obscured and clearly distinguished; grade II (intermediate); and grade III (fleshy), in which the episcleral vessels are totally obscured. Exclusion criteria included any condition for which bevacizumab was contraindicated (allergy to bevacizumab, proteinuria, bleeding tendencies, previous myocardial infarction or stroke, pregnancy, and lactation), evidence of other ocular diseases except refraction errors, use of topical medications for pterygium, presence of other complaints not attributable to pterygium, prior ocular trauma, more than one recurrent pterygia, and the inability to follow-up for the entire duration of the study.

Patients were interviewed before injection using a questionnaire to obtain information such as general data, contact number, demographic factors, and medical, surgical, and ocular history.

Informed consent was obtained from all patients after the nature and possible consequences of the study were explained. The study was approved by the Institutional Research Ethics Committee. In cases of bilateral recurrent pterygium, only the worst eye was treated.

All injections were administered by a single investigator in an operating room. Eyes were anesthetized with topical proparacaine hydrochloride drops. A subconjunctival injection of $0.5 \mathrm{~mL}$ of bevacizumab (Avastin ${ }^{\circledast} 2.5$ mg/0.1 mL, F. Hoffmann-La Roche, Basel, Switzerland) was administered at the limbus, adjacent to the pathological blood vessels growing/sprouting into the cornea. Using an eyelid speculum, injections were administered at the slit lamp following application of topical anesthetic eyedrops. After surgery, patients were treated with topical Cilodex ${ }^{\oplus}$ (ciprofloxacyn and dexamethasone, Alcon Laboratories Ltd.) eye drops 4 times daily for 15 days.

As per our protocol, all eyes received a single bevacizumab injection. All eyes were biomicroscopically examined before surgery, 2 and 7 days after surgery, and 1 and 2 months after surgery. Complete opthalmological evaluation was performed for each patient. This included visual acuity determination, applanation tonometry, slit-lamp examination, and anterior segment photography. At each visit, 2 digital corneal photographs were obtained using a digital camera. The size of pterygium was measured horizontally from the limbus to the apex and graded according to the system used by Tan et al. using the slit-lamp microscope ${ }^{(6)}$.

Any complications and adverse events were noted. The same photographer captured images of the anterior segment using the same camera at every follow-up visit. Postinjection complications such as ocular surface toxicity, corneal abrasion, persistent epithelial defect, subconjunctival hemorrhage, and infection were noted, as was any change in the size and vascularity of pterygium.

Statistical analyses were performed using SPSS version 18.0 (SPSS, Chicago, IL). The paired t test was used to compare changes in the size of pterygia, and the Friedman test was used to determine the significance of changes after treatment. Probabilities of less than 5\% were considered statistically significant.

\section{RESULTS}

The study group comprised 36 eyes of 36 patients with recurrent pterygium. These included 18 males (50\%) and 18 females (50\%) with a mean age of 58.75 years (SD, 10.98 years). Close to one-third (30.6\%) of the patients had recurrent pterygia in both eyes. The left and right eyes were affected in $47.2 \%$ and $22.2 \%$ patients, respectively. Approximately $44.4 \%$ patients were from Goiânia (Brazil), while 55.6\% were from other cities. More than half the patients (58.3\%) had a family history of pterygium.

According to the results of graph 1 (paired-samples test), there was a significant difference in the size (in $\mathrm{mm}$ ) of pterygium at different intervals $(P<0.05)$ after the injection of bevacizumab.

Table 1 represents the distribution of patients according to the classification of Tan et al. ${ }^{(6)}$ before and 60 days after one injection of $0.5 \mathrm{~mL}$ of bevacizumab $(2.5 \mathrm{mg} / 0.1 \mathrm{~mL}$ ). There was a difference in the gradation of pterygium before and after application.

The mean surface area was decreased. There was a significant difference in the gradation according to the system used by Tan et al ${ }^{(6)}$ at different intervals $(P<0.05)$, particularly 30 days after injection.

Approximately two-thirds (66.7\%) of the patients presented with hyposphagma on the $2^{\text {nd }}$ day after subconjunctival injection; this decreased to $30.6 \%$ by day 7 and to $0 \%$ at 1 month. Most patients (69.4\%) exhibited amelioration of irritative symptoms within 2 days, $88.9 \%$ patients after 7 days, and $97.2 \%$ after 1 month. The aspect of the recurrent pterygium after injection did not change considerably (Figure 1).

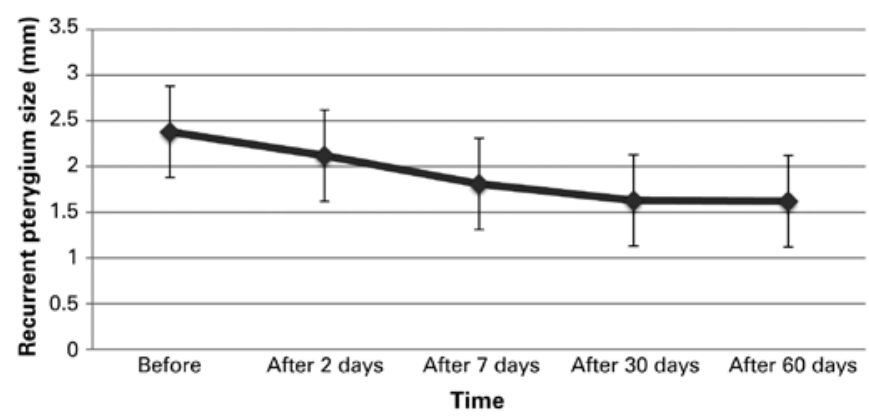

Graph 1. There was a significant change in the size of pterygium at different intervals $(P<0.05$; paired t-test) after the injection of bevacizumab. The mean pterygium size ranged from $2.37 \mathrm{~mm}$ to $1.61 \mathrm{~mm}$. These patients were only the treated ones.

\begin{tabular}{|c|c|c|c|}
\hline & Pre & 60-day visit & Total \\
\hline Grade I & $6(16.7 \%)$ & 15 (41.7\%) & 21 \\
\hline Grade II & $20(55.6 \%)$ & $17(47.2 \%)$ & 37 \\
\hline Grade III & $10(27.8 \%)$ & $4(11.1 \%)$ & 14 \\
\hline Total & 36 & 36 & 72 \\
\hline
\end{tabular}




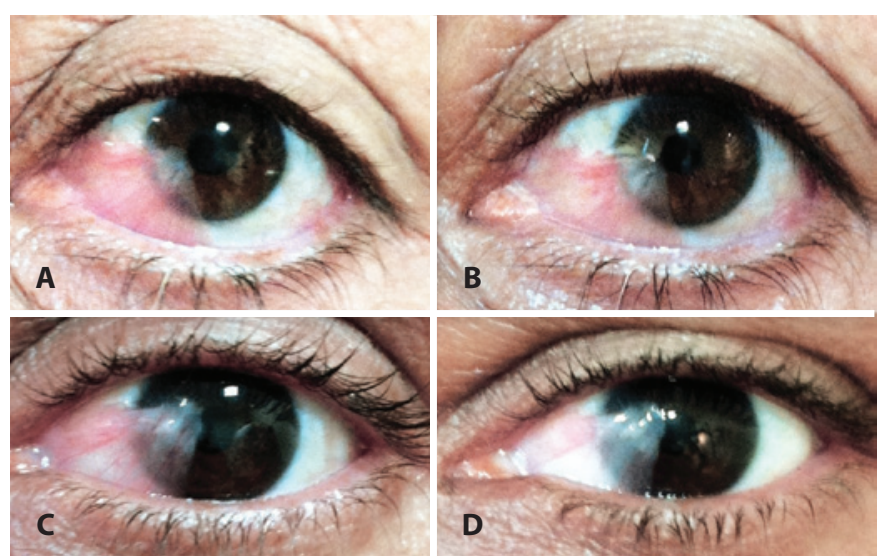

Figure 1. A and C) Before subconjuntival application of bevacizumab in recurrent pterygium. $B$ and D) 60 days after de application.

\section{DISCUSSION}

In recent years, anti-VEGF agents such as bevacizumab and ranibizumab have been evaluated as an adjunctive therapy for pterygium along with surgical excision or as a nonsurgical therapy ${ }^{(20)}$.

Recent studies have reported successful outcomes after the administration of bevacizumab for the treatment of corneal neovascularization. Erdurmus and Totan ${ }^{(21-22)}$ evaluated the efficacy of subconjunctival bevacizumab injection $(2.5 \mathrm{mg} / 0.1 \mathrm{~mL})$ in 2 patients with corneal neovascularization along with the associated etiologies. One patient had dry eye and exhibited significantly regression of vessels a week after injection, while the other patient had a failed graft and exhibited only minor vessel regression. Awadein ${ }^{(23)}$ described 3 patients with corneal neovascularization after keratoplasty who were treated with a single subconjunctival injection of $2.5 \mathrm{mg}$ bevacizumab. In all patients, the number and caliber of blood vessels decreased after injection. The regression of the corneal new vessels was more marked in patients with smaller and/or fewer blood vessels. However, in patients with old and rejected vascularized grafts, there was little change in the number and caliber of blood vessels ${ }^{(21)}$.

Recently, several studies have been conducted to evaluate the effects of local therapy with bevacizumab on both primary and recurrent pterygium ${ }^{(24-27)}$. Bevacizumab has been used at various doses at various times by different routes of administration. Nonetheless, the results remain limited and controversial, and there is no clear randomized controlled trial that has studied the efficacy of subconjunctival bevacizumab in patients with impending recurrent pterygium ${ }^{(28-30)}$.

A single administration of an arbitrary dose based on the intravitreal preparation of bevacizumab may be inadequate. A single dose of $1.25 \mathrm{mg}$ of intravitreal bevacizumab has been reported to provide complete intravitreal VEGF blockade for a minimum of 4 weeks, with an intravitreal bevacizumab half-life of approximately 3 days ${ }^{(28)}$. However, the conjunctival half-life of the drug may be shorter than the vitreous half-life because of the higher systemic absorption through the abundant conjunctival vessels ${ }^{(24)}$. Repeat injections or higher doses of bevacizumab may be required to achieve better outcomes. Nevertheless, increased or multiple doses may be accompanied by significant side effects.

Our study illustrated that a single subconjunctival dose of bevacizumab dose is partly efficacious in decreasing conjunctival vascularization in the impending recurrent pterygium compared with that at baseline. Nevertheless, the favorable effect was incomplete and temporary, similar to that reported by Leippi et al. ${ }^{(25)}$.

Previous reports suggesting the effective role of subconjunctival bevacizumab were noncomparative case reports ${ }^{(25,28,31)}$. Corneal neovascularization was inhibited or regressed, but not completely elimi- nated. Delayed recurrence was observed in a study by Fallah et al., who used topical bevacizumab to inhibit the growth of impending recurrent pterygium in 26 eyes, although the pterygia eventually extended onto the cornea ${ }^{(17)}$.

Other factors such as tumor necrosis factor al pha, bFGF, TGF- $\beta$, and platelet-derived growth factor (PDGF) have been shown to correlate with the formation and recurrence of pterygium. Immunoreactivity for these growth factors was located in epithelial cells, endothelial cells of vessels, basement membranes of vessels, and the epithelium, fibroblasts, and infiltrating inflammatory cells in pterygium ${ }^{(28,29)}$.

\section{CONCLUSIONS}

The limitations of this study include the short duration of follow-up, the lack of a control group, the limited number of patients, and the difficulty in objectively measuring the size of recurrent pterygia before and after injection.

Further studies with larger sample sizes will be required to determine the appropriate dosing schedule, efficacy, and safety profile. In addition, anti-VEGF treatment may have a greater synergistic effect when combined with treatment targeting alternate cytokines and growth factors and should be investigated in future studies. New antiangiogenic therapies will hopefully focus more on facilitating delivery into tissue, increasing the duration of effect while continuing to minimize adverse side effects.

In summary, a single administration of subconjunctival bevacizumab to recurrent pterygium was well tolerated and decreased irritation and vascularization for a short term. The transient effect was likely related to the limited bioavailability of the drug in the setting of continued VEGF expression.

\section{REFERENCES}

1. Hill JC, Maske R. Pathogenesis of pterygium. Eye (Lond). 1989;3(Pt 2):218-26.

2. Cameron ME. Histology of pterygium: An electron microscopic study. Br J Ophthalmol. 1983;67(9):604-8.

3. Cilova-Atanasova B. On the pathogenesis of pterygium. Folia Med (Plovdiv). 1971 13(2):67-74.

4. Mauro J, Foster CS. Pterygia: pathogenesis and the role of subconjunctival bevacizumab in treatment. Semin Ophthalmol. 2009;24(3):130-4

5. Hosseini H, Nejabat M, Khalili MR. Bevacizumab (Avastin) as a potentialnovel adjunct in the management of pterygia. Med Hypotheses. 2007;69(4):925-7.

6. Tan DT, Chee SP, Dear KB, Lim AS. Effect of pterygium morphology on pterygium recurrence in a controlled trial comparing conjunctival autografting with bare sclera excision. Arch Ophthalmol. 1997;115(10):1235-40. Erratum in: Arch Ophthalmol. 1998; 116(4):552.

7. Busin M, Halliday BL, Arffa RC, McDonald MB, Kaufman HE. Precarved lyophilized tissue for lamellar keratoplasty in recurrent pterygium. Am J Ophthalmol. 1986;102(2):222-7.

8. Kria L, Ohira A, Amemiya T. Immunohistochemical localization of basic fibroblast growth factor, platelet derived growth factor, transforming growth factor-beta and tumor necrosis factor-alpha in the pterygium. Acta Histochem. 1996;98(2):195-201.

9. Kria L, Ohira A, Amemiya T. Growth factors in cultured pterygium fibroblasts: immunohistochemical and ELISA analysis. Graefes Arch Clin Exp Ophthalmol. 1998;236(9):702-8.

10. Lee JK, Song YS, Ha HS, Park JH, Kim MK, Park AJ, et al. Endothelial progenitor cells in pterygium pathogenesis. Eye (Lond). 2007;21(9):1186-93.

11. Jin J, Guan M, Sima J, Gao G, Zhang M, Liu Z, et al. Decreased pigment epitheliumderived factor and increased vascular endothelial growth factor levels in pterygia. Cornea. 2003;22(5):473-7.

12. Hurwitz H, Fehrenbacher L, Novotny W, Cartwright T, Hainsworth J, Heim W, Bevacizumab plus irinotecan, fluorouracil, and leucovorin for metastatic colorectal cancer. N Engl J Med. 2004;350(23):2335-42. Comment in: N Engl J Med. 2004;350(23):2406-8; Nat Clin Pract Gastroenterol Hepatol. 2004;1 (2):72-3; Cancer Treat Rev. 2004;30(8):715-7; N Engl J Med. 2004;351(16):1690-1; author reply 1690-1.

13. Rosenfeld PJ, Moshfeghi AA, Puliafito CA. Optical coherence tomography findings after an intravitreal injection of bevacizumab (Avastin) for neovascular age related macular degeneration. Ophthalmic Surg Laser Imaging. 2005;36(4):331-5. Comment in: Ophthalmic Surg Lasers Imaging. 2005;36(4):270-1.

14. Avery RL, Pieramici DJ, Rabena MD, Castellarin AA, Nasir MA, Giust MJ. Intravitreal bevacizumab (Avastin) for neovascular age-related macular degeneration. Ophthalmology. 2006;113(3):363-72. Comment in: Ophthalmology. 2007;114(2):400; author reply 400-1.

15. Wu PC, Kuo HK, Tai MH, Shin SJ. Topical bevacizumab eye drops for limbal: conjunctival neovascularization in impending recurrent pterygium. Cornea. 2009;28(1):103-4. 
16. Di Girolamo N, Coroneo MT, Wakefield D. Active matrilysin (MMP-7) in human pterygia: potential role in angiogenesis. Invest Ophthalmol Vis Sci. 2001:42(9):1963-8.

17. Fallah MR, Khosravi K, Hashemian MN, Beheshtnezhad AH, Rajabi MT, Gohari M. Efficacy of topical bevacizumab for inhibiting growth of impending recurrent pterygium. Curr Eye Res. 2010;35(1):17-22.

18. Shenasi A, Mousavi F, Shoa-Ahari S, Rahimi-Ardabili B, Fouladi RF. Subconjunctiva bevacizumab immediately after excision of primary pterygium: the first clinical trial. Cornea. 2011;30(11):1219-22.

19. Lekhanont K, Patarakittam T, Thongphiew P, Suwan-apichon O, Hanutsaha P. Randomized controlled trial of subconjunctival bevacizumab injection in impending recurrent Pterygium: a pilot study. Cornea. 2012;31(12):155-61

20. Ozgurhan EB, Alper A, Kara N, Yuksel K, Dermican A, Demirok A. Topical application of bevacizumab as an adjunct to recurrent pterygium surgery Cornea. 2013:32(6):835-8.

21. Fallah T, Tafti MR, Khosravifard K, Mohammadpour M, Hashemian M, Kiarudi M. Efficacy of intralesional bevacizumab injection in decreasing pterygium size. Cornea. 2011:30(2):127-9.

22. Erdurmus M, Totan Y. Subconjunctival bevacizumab for corneal neovascularization Graefes Arch Clin Exp Ophthalmol. 2007;245(10):1577-9.

23. Awadein, A. Subconjunctival bevacizumab for vascularized rejected corneal grafts. $\rfloor$ Cataract Refract Surg. 2007;33(11):1991-3
24. Spaide RF, Fisher YL. Intravitreal bevacizumab (Avastin) treatment of proliferative diabetic retinopathy complicated by vitreous hemorrhage. Retina. 2006:26(3):275-8.

25. Leippi S, Grehn F, Geerling G. [Antiangiogenic therapy for pterygium recurrence]. Ophthalmologe. 2009;106(5):413-9. German.

26. Wu PC, Kuo HK, Tai MH, Shin SJ. Topical bevacizumab eyedrops for limbalconjunctival neovascularization in impending recurrent pterygium. Cornea. 2009; 28(1):103-4

27. Bahar I, Kaiserman I, McAllum P, Rootman D, Slomovic A. Subconjunctival bevacizumab injection for corneal neovascularization in recurrent pterygium. Curr Eye Res. 2008 33(1):23-8.

28. Beer PM, Wong SJ, Hammad AM, Falk NS, O'Malley MR, Khan S. Vitreous levels of unbound bevacizumab and unbound vascular endothelial growth factor in two patients. Retina. 2006;26(8):871-6.

29. Mansour AM. Treatment of infl amed pterygia or residual pterygial bed. Br J Ophthalmol. 2009;93(7):864-5

30. Enkvetchakul O, Thanathanee O, Rangsin R, Lekhanont K, Suwan-Apichon O A randomized controlled trial of intralesional bevacizumab injection on primary pterygium: preliminary results. Cornea. 2011;30(11):1213-8.

31. Shahin MM, Elbendary AM, Elwan MM. Intraoperative subconjunctival bevacizumab as an adjunctive treatment in primary pterygium: a preliminary report. Ophthalmic Surg Lasers Imaging. 2012;43(6):459-66.

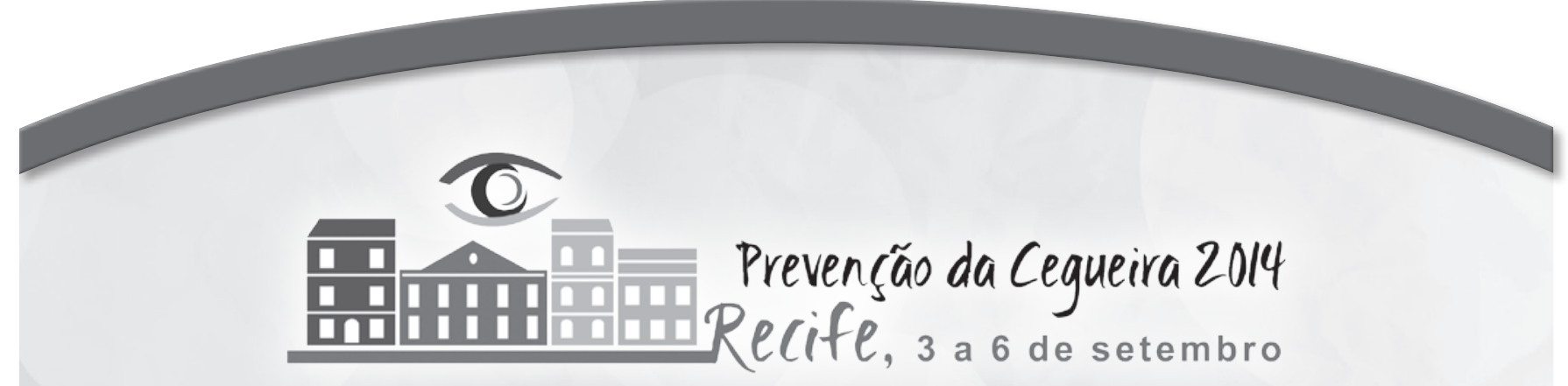

\section{Congresso Brasileiro de Prevenção da Cegueira e Reabilitação Visual}

\section{Congresso de Oftalmologia de Língua Portuguesa}

\section{3 a 6 de setembro de 2014}

Centro de Convenções de Pernambuco

Recife (PE)

\section{Informações:}

ASSESSOR - Assessoria e Marketing

Tels.: (81) 3423-1300 / 9172-7580

E-mail:comercial1@cbo2014.com.br

\section{MAIS Eventos}

Tels.: (81) 3033-5147 / 81 8129-4354

E-mail: comercial2@.cbo2014.com.br

Site: http:/ /www.congressocbo.com.br/cbo2014/ 